\title{
Amelioration of ethanol intoxicated ovarian dysfunction by Alocasia indica tuber: possible involvement of nuclear factor kappa B
}

\author{
Swagata Pal', Ankita Bhattacharjee², Oly Banerjee², Shilpi K. Prasad², \\ Siddhartha Singh ${ }^{2}$, Sandip Mukherjee ${ }^{2 *}$
}

${ }^{1}$ Department of Physiology, Raja Peary Mohan College, Uttarpara, Hooghly 712258, West Bengal, India

${ }^{2}$ Department of Physiology, Serampore College, Hooghly 712201, West Bengal, India

${ }^{*}$ Corresponding author, E-mail: sm_kdc@yahoo.co.in

\begin{abstract}
The protective efficacy of ethanolic extract of Alocasia indica tuber was studied on ethanol-intoxicated ovaries of rats, searching for the possible involvement of expression levels of nuclear factor kappa B (NF- $\mathrm{kB}$ ) and caspase-3. The extract was prepared by $80 \%$ ethanol using Soxhlet. Female albino rats were intraperitoneally injected by ethanol ( $3 \mathrm{~g} \mathrm{~kg}^{-1}$ body weight per day) with and without extract (200 and $400 \mathrm{mg} \mathrm{kg}^{-1}$ body weight per day) for a period of 14 days. Oxidative stress parameters and the gonadal hormone profile were determined, and apoptosis assay and immuno-staining of NF- $\mathrm{\kappa B}$ and caspase- 3 were conducted. Oxidative stress parameters and antioxidant enzyme levels were regained by 41 to $90 \%$ and 36 to $96 \%$, respectively, by extract at a higher dose in ethanol intoxicated rat. Decreased levels (18 to $28 \%$ ) of follicle stimulating hormone, luteinizing hormone, estrogen and progesterone level due to ethanol intoxication were restored (19 to 98\%) by extract at same dose, whereas elevated level of prolactin and corticosterone level were restored by 51 to $81 \%$. The extract reduced number of apoptotic dead cells in the ovary with altered expression of NF- $\kappa \mathrm{B}$ and caspase-3, indicated by lower number of positively stained cells in extract-treated rats. It appears that ethanolic extract of $A$. indica can suppress ethanolinduced ovarian apoptotic cell death and other reproductive changes.
\end{abstract}

Key words: Alocasia indica, apoptosis, caspase-3, ethanol toxicity, ovary, NF- $\kappa \mathrm{B}$.

Abbreviations: CAT, catalase; FSH, follicle-stimulating hormone; GSH, reduced glutathione; LH, luteinizing hormone; NF-kB, nuclear factor kappa B; ROS, reactive oxygen species; SOD, superoxide dismutase.

\section{Introduction}

Alcohol consumption is used for celebration and recreation since ancient times, but excessive alcohol drinking on a daily basis creates several adverse health outcomes such as liver diseases, stroke, digestive problems, cancer, infertility etc. The effect of alcohol consumption is detrimental for both male and female, and it was reported that a given oral dose of alcohol may produce a higher blood ethanol concentration in females than males (Cederbaum 2012). On the other hand women are more affected than males due to greater physiological sensitivity of women than male to the effect of alcohol (Ely et al. 1999). Women with excessive drinking habits develop more medical problems such as sex-related factors, including differences in alcohol pharmacokinetics, and its effect on brain function and the levels of sex hormones may contribute to some of those differences (Erol et al. 2015). The dependence of alcohol in women elevates the risk of several disorders of menstrual cycle function, including amenorrhea, luteal phase dysfunction, anovulation, and, in some cases, early menopause, which can lead to perpetual sexual dysfunction (Waldron et al. 2008).

Alcohol-induced changes are related with production of reactive oxygen species (ROS). The involvement of oxidative stress in the pathophysiology of infertility (Agarwal et al. 2005) and early pregnancy loss was also reported (Emanuele et al. 2002). In the case of chronic alcoholism, production of ROS can impair the oxidantantioxidant profile (Albano 2006), which escalates lipid peroxidation as well as modification of proteins, as a result of tissue damage (Kono et al. 2001). However, another investigation showed that that administration of antioxidants, which lower the levels of free iron or restore reduced glutathione levels, can mitigate the detrimental outcomes of alcohol intoxication (Kono et al. 2001). Excess cellular production of ROS causes damage to proteins, nucleic acids, lipids, membranes and organelles, which can lead to activation of cell death processes such as apoptosis (Redza-Dutordoir et al. 2016). The onset of apoptosis is associated with the proteolytic activation of caspases. Caspase- 3 is promoted during the early stage of apoptosis 
and the activated form is a marker for cells undergoing apoptosis (Mlejnek 2001). Furthermore, NF- $\mathrm{kB}$ is a major regulator of the inflammatory reaction, which controls the expression of pro-inflammatory molecules in response to oxidative stress and other infectious agents (Tegeder et al. 2001).

In India, the tradition of Ayurveda (healing of illness or sickness through herbal remedies) has been in rage since ancient times. According to the World Health Organization, $80 \%$ of the population of developing and third world countries, who cannot afford synthetic pharmaceutical drugs, depend on conventional plantbased medications to treat several ailments with minimal side effects (Srilatha, Ananda 2014). This has caused an urge to explore for more potent and contemporary natural antioxidants of pharmaceutical use. Alocasia indica (Roxb.) Schott, family Araceae, locally known as "Mannkachu", is extensively cultivated in tropical and sub-tropical regions, especially in the West Bengal, Assam, Maharashtra and Southern parts of India. A. indica has been used as a folklore remedy for gastrointestinal disorders in several regions of India. Different parts of this plant are traditionally used in diseases of the abdomen, spleen, and in inflammation (Kirtikar, Basu 1975). The whole plant is used in Kavirajes medicine in different districts of India and Bangladesh as a remedy of tiger bite, rheumatoid arthritis, and itching (Rahmatullah et al. 2009). The plant contains ascorbic acid, malic acid, gallic acid, oxalic acid, amino acids, succinic acid, flavonoids, and glycosides (Prajapati 2003). Our study group earlier reported that ethanolic extract of the edible tuber part of $A$. indica contained phenolic compounds that exhibited strong antioxidant properties (Pal et al. 2014a) and had potent hepatoprotective activity against ethanol intoxication (Pal et al. 2014b) as well as radioprotective effect (Prasad et al. 2019). However, currently the protective efficacy of $A$. indica on reproductive functions is unexplored and its underlying mechanism needs detailed examination. This study was undertaken to investigate the possible ameliorating effects of the ethanolic extracts of A. indica tuber on several aspects of female reproductive functions in ethanol intoxicated rats, including prevention of ovarian apoptotic cell death by altering NF- $\mathrm{\kappa B}$ and caspase-3 expression.

\section{Materials and methods}

\section{Plant material}

The tuber vegetable Alocasia indica (Roxb.) Schott (Araceae) was collected from the local market of Kolkata, West Bengal, India and was authenticated by the Botany Department of Serampore College, Hooghly, India. Voucher specimens were entered in the Department of Botany, Serampore College under registry No. PHYSIOL/ $\mathrm{SP} / 2018 / 001$. The tuber was chopped $(5 \times 5 \mathrm{~cm})$ and dried under sun $\left(40 \pm 5^{\circ} \mathrm{C}\right)$ for a week. The dried tuber was finely powdered in a grinder and sieved through a 40-micron sieve and stored in airtight containers.

\section{Preparation of ethanolic extract of A. indica tuber}

Dried and powdered tuber of $A$. indica $(100 \mathrm{~g})$ was extracted in $500 \mathrm{~mL}$ of $80 \%(\mathrm{v} / \mathrm{v})$ ethanol for $72 \mathrm{~h}$ in a Soxhlet apparatus and the extract was centrifuged for 15 min at $4000 \mathrm{rpm}$. Supernatant was concentrated using a rotary evaporator; residual alcohol was dried in lyophilizer and was kept at $-20^{\circ} \mathrm{C}$ for further use.

\section{Induction of alcohol toxicity in rat ovary}

Female Wistar rats weighing $110 \pm 4.5 \mathrm{~g}$ were maintained in the Central Animal House (IICB, Kolkata) at a $12 \mathrm{~h}$ light/ dark cycle and at $25 \pm 2{ }^{\circ} \mathrm{C}$. All animal experiments were performed according to the ethical guidelines suggested by the Institutional Animal Ethics Committee of Serampore College. The animals were distributed into four groups with five rats in each group and provided with a control diet composed of carbohydrate (71\%), protein (18\%), fat (7\%), and salt mixture (4\%) (Pal et al. 2014b). The experimental group of animals received alcohol by intraperitoneal injection at the dose of $3 \mathrm{~g}$ ethanol (15\%, v/v) per kg body weight per day for 14 days (Pal et al. 2014b). Absolute ethanol was diluted with $0.9 \%(\mathrm{w} / \mathrm{v}) \mathrm{NaCl}$ to obtain the desired concentration.

Lyophilized dried ethanol extract of $A$. indica tuber (1 g) was dissolved in $12.5 \mathrm{~mL}$ of normal saline $(0.9 \% \mathrm{NaCl})$ and was given intraperitoneally according to dose and body weight of animal by the following manner after performing the routine toxicity tests of the extract (Pal et al. 2014b). The experiment was designed as follows.

Group 1: control animals (C) received a normal diet and were injected with normal saline ( $0.9 \%$ sodium chloride) for 14 days.

Group 2: animals were intraperitonially injected with ethanol ( $3 \mathrm{~g} \mathrm{~kg}^{-1}$ body weight per day) for 14 days. This group was denoted by experimental (E) group.

Group 3: animals were intraperitonially injected with ethanol (3 $\mathrm{g} \mathrm{kg}^{-1}$ body weight/d) followed by ethanolic extract of $A$. indica tuber ( $200 \mathrm{mg} \mathrm{kg}^{-1}$ body weigh per day) for 14 days [E+AI200].

Group 4: animals were intraperitonially injected with ethanol ( $3 \mathrm{~g} \mathrm{k}^{-1}$ body weight per day) followed by ethanolic extract of $A$. indica tuber ( $400 \mathrm{mg} \mathrm{kg}^{-1}$ body weigh per day) for 14 days [E+AI400].

After the experimental period (14 days), all of the rats were anesthetized with pentobarbitone sodium $\left(60 \mathrm{mg} \mathrm{kg}^{-1}\right.$ body weight) and sacrificed by cervical dislocation. Blood samples were drawn from heart in two separate test tubes: one with anticoagulant and another without anticoagulant. Serum and plasma were separated for biochemical analysis; ovary was immediately separated for biochemical, histopathological and immunocytochemical evaluations. All estimations were executed in triplicate. 


\section{Preparation of ovarian tissue extract}

The abdomen was opened, and the ovaries were quickly removed. For the measurement of nitric oxide (NO), malondialdehide (MDA), and superoxide dismutase (SOD), ovarian tissue extract was homogenized in icecold Tris- $\mathrm{HCl}$ buffer ( $\mathrm{pH}$ 7.4). For catalase (CAT) and reduced glutathione ( $\mathrm{GSH})$ measurement, the tissues were homogenized in ice-cold isotonic phosphate buffer $(\mathrm{pH} 7.0$ and $\mathrm{pH} 8.0$, respectively).

\section{Estimation of nitric oxide production}

Nitric oxide decomposes rapidly in aerated solutions to form stable nitrite/nitrate products. Therefore, nitrite accumulation was calculated by Griess reaction (Pal et al. 2014a) and was used as an index of NO production. A sodium nitrite standard curve was used to calculate the amount of nitrite (micromolar unit) present in the sample.

\section{Measurement of lipid peroxidation}

Lipid peroxidase activity was assessed by measuring the formation of malondialdehyde (MDA), which acts as an indicator of the lipid peroxidation level. Quantitative measurement of lipid peroxidation was done following the thiobarbituric acid test (Pal et al. 2014a). The amount of MDA formed was quantified with thiobarbituric acid and used as an index of lipid peroxidation. The results were expressed as nmoles of MDA per mg of protein using the molar extinction coefficient $\left(\varepsilon=155 \mathrm{mM}^{-1} \mathrm{~cm}^{-1}\right)$.

\section{Measurement of superoxide dismutase activity}

The SOD activity was estimated by the nitroblue tetrazolium method, which is based on the inhibition of nitroblue tetrazolium reduction by SOD (Pal et al. 2014a). The relative absorbance was then converted into units of SOD activity per mg protein, where one unit of SOD activity was equivalent to the quantity of SOD that resulted in a $50 \%$ reduction in the background rate of nitroblue tetrazolium reduction.

\section{Measurement of catalase activity}

Catalase activity was determined by the decomposition of $\mathrm{H}_{2} \mathrm{O}_{2}$ at $240 \mathrm{~nm}$ at $25{ }^{\circ} \mathrm{C}$ (Pal et al. 2014a). $\mathrm{H}_{2} \mathrm{O}_{2}$ solution in an amount of $0.2 \mathrm{~mL}\left(10 \mathrm{mM} \mathrm{H}_{2} \mathrm{O}_{2}\right.$ in $50 \mathrm{mM}$ potassium phosphate buffer, $\mathrm{pH}$ 7.0) was mixed with 0.1 $\mathrm{mL}$ of ovary homogenates and decrease of absorbance in every $30 \mathrm{~s}$ over a period of $3 \mathrm{~min}$ was recorded. Changes in the rate of absorbance were converted into units of catalase per mg protein using a conversion factor (3.45), which corresponds to the decomposition of $3.45 \mu$ moles of hydrogen peroxide in a reaction mixture producing a decrease in the absorbance from 0.45 to 0.40 units.

\section{Measurement of reduced glutathione concentration}

The GSH concentration was measured using 5,5'-dithiobis2-nitrobenzoic acid. The absorbance of reduced chromogen was determined spectrophotometrically at $412 \mathrm{~nm}$. The GSH level was evaluated from a standard curve and expressed as mM per mg protein (Pal et al. 2014a).

\section{Measurement of protein}

Protein in the ovarian tissue was estimated by the method of Lowry et al. (1951) using bovine serum albumin as a standard.

\section{Measurement of plasma biochemical indicators}

Plasma concentrations of luteinizing hormone ( $\mathrm{LH})$ and follicle-stimulating hormone (FSH), estrogen, progesterone, prolactin and corticosterone were estimated by using an ELISA kit obtained from DRG Inc., Germany. The sensitivity for estrogen and progesterone were 0.75 pg $\mathrm{mL}^{-1}$ and $0.1 \mathrm{ng} \mathrm{mL}^{-1}$, respectively. To avoid batch to batch variation, all samples were run at one time, and were assayed in duplicate.

\section{Histological and immunocytochemical studies}

Permanent slides of the ovaries were prepared and stained with eosin-haematoxylin for histopathological evaluation. Ovarian tissue from all groups of animals was taken and Bouin's-fixed. Paraffin blocks were prepared, and 4 to $5 \mu \mathrm{m}$ thin sections were cut with a rotary microtome and routine microscopic slides were prepared.

Haematoxylin and eosin-stained slides were examined by light microscopy (Carl Zeiss, Primostar model) for histological evaluation.

Apoptosis was estimated by the TUNEL assay, which relies on the incorporation of labelled dUTP at sites of DNA fragments. Sections of 5-mm thickness were deparaffinized and rehydrated in descending alcohol concentrations. Apoptotic cells in ovarian tissue were detected using an Apo-BrdU-IHC In-situ DNA fragmentation assay kit obtained from BioVision, Milpitas, CA.

Immunocytochemical detection of NF- $\kappa \mathrm{B}$ and caspase- 3 were done by the method of Giakoustidis et al. (2008). Ovary sections of 5 to $6 \mu \mathrm{m}$ thickness were deparaffinized, rehydrated in descending alcohol concentrations and boiled in $10 \mathrm{mM}$ sodium citrate ( $\mathrm{pH} \mathrm{6.0)}$ for $30 \mathrm{~min}$. Then the slides were maintained at sub-boiling temperature for $10 \mathrm{~min}$ and then cooled to room temperature. They were then washed with distilled water for $5 \mathrm{~min}$ and incubated in $3 \% \mathrm{H}_{2} \mathrm{O}_{2}$ for $10 \mathrm{~min}$. Sections were incubated with PBS and then with a blocking solution of normal goat serum at a dilution of 1:5 for $1 \mathrm{~h}$. Sections without washing were incubated with the cleaved caspase-3 (Asp 175) antibody (Cell Signaling Technology Inc., Danvers, MA) at a dilution of 1:200 or NF- $\kappa$ B p65 antibody at a dilution of 1:1000 (Cell Signaling Technology Inc., Danvers, MA) overnight at 48 ${ }^{\circ} \mathrm{C}$. The next day, the sections were washed thoroughly and incubated with the secondary antibody, ie. goat antirabbit biotin conjugate (Sigma-Aldrich, St. Louis, MO), at dilution of 1:300 for $30 \mathrm{~min}$ at room temperature. The 
sections then were incubated with extrAvidin peroxidase conjugate (Sigma-Aldrich) for $30 \mathrm{~min}$ at room temperature at dilution of 1:300 and finally were monitor stained closely with diaminobenzidine tablets (Sigma-Aldrich). After washing, the sections were dehydrated in ascending alcohol concentrations, mounted, and examined under a light microscope.

\section{Statistics}

Data were expressed as mean \pm SE. The Kruskal-Wallis non-parametric ANOVA test was performed to determine whether results from different groups differed significantly. To test intergroup significant differences, the MannWhitney $\mathrm{U}$ multiple comparison test was performed. Differences were considered significant if $p<0.05$.

\section{Results}

To further elucidate the involvement of oxidative stremediated damage in the mechanism underlying the toxicological effects induced by ethanol on the ovarian tissue of rats, NO production, lipid peroxidation, GSH concentration, and CAT and SOD activity in ovarian tissue homogenates were measured.

Both MDA and NO concentration, trademarks of lipid peroxidation and inflammatory response, were significantly increased in ethanol-treated rats. The enhanced MDA concentration $(20.99 \%, p<0.01)$ and NO production $(79.67 \%, p<0.01)$ in ethanol-treated rats decreased by $58.48 \%(p<0.01)$ and 59.1\% $(p<0.01)$, respectively, following supplementation with ethanol extract of $A$. indica tuber at the concentration of $200 \mathrm{mg} \mathrm{kg}^{-1}$ body weight per day (Table 1). Ethanol extract of $A$. indica tuber at $400 \mathrm{mg}$ $\mathrm{kg}^{-1}$ body weight per day caused a significant decrease in both MDA concentration by $71.73 \%(p<0.01)$ and NO level by $70.78 \%(p<0.01)$.

Ethanol intoxication caused significant decrease in the tissue GSH concentration $(26.89 \%, p<0.01)$ of the ovary, compared to the control group (Table 1). Although the ethanol-induced decrease in tissue GSH concentrations of ovary was increased by supplementation with tuber extract at $200 \mathrm{mg} \mathrm{kg}^{-1}$ body weight per day, the result was found to be statistically insignificant. However, the reduced GSH content of ovary following ethanol intoxication were reversed significantly by supplementation with tuber extract $(90.9 \%, p<0.01)$ at a concentration of $400 \mathrm{mg} \mathrm{kg}^{-1}$ body weight per day (Table 1).

In addition, after intoxication with ethanol, a decline in the activity of CAT $(67.68 \%, p<0.01)$ was detected in the ethanol-treated animals, in comparison to the control animals. The reduced CAT activity returned to a near normal level after tuber extract supplementation at 200 and $400 \mathrm{mg} \mathrm{kg}^{-1}$ body weight per day $(57.81 \%, p<0.01$ and $96.14 \%, p<0.01$, respectively). Furthermore, the SOD activity was significantly lower $(29.17 \%, p<0.01)$ in the ethanol-injected group, while this reduced SOD activity was increased by $36.30 \%(p<0.01)$ and $78 \%(p<0.01)$ following tuber extract supplementation, respectively, at 200 and $400 \mathrm{mg} \mathrm{kg}^{-1}$ body weight per day (Table 1).

The effect of administration of tuber extract on ethanolinduced changes in gonadotropins was also explored in the present study. In comparison to the control, concentration of luteinizing hormone (LH) and follicle-stimulating hormone (FSH) were drastically decreased in ethanoltreated rats, by $27.66 \%(p<0.01)$ and $18.84 \%(p<0.01)$, respectively (Table 2 ). Both $\mathrm{LH}$ and FSH concentrations recovered significantly, by $43.36 \%(p<0.05)$ and $86.31 \%(p$ $<0.01$ ), respectively, in ethanol-treated rats supplemented with $200 \mathrm{mg} \mathrm{kg}^{-1}$ body weight per day of tuber extract. Higher dose of the extract ( $400 \mathrm{mg} \mathrm{kg}^{-1}$ body weight per day) resulted in considerable recovery of ethanol-induced alterations in LH concentration by $43.80 \%(p<0.05)$ and FSH concentration by $66.31 \%(p<0.05)$ (Table 2$)$.

Ethanol stress impaired the gonadal hormone profile by decreasing both estrogen and progesterone concentration significantly, by $27 \%(p<0.05)$ and $28 \%(p$ $<0.01$ ) (Table 2), respectively, compared to the control. Estrogen concentration recovered towards control levels by 46.24\% $(p<0.05)$ when supplemented with $200 \mathrm{mg} \mathrm{kg}^{-1}$ body weight per day of tuber extract following ethanol administration, and further by $98.54 \%(p<0.01)$ with a higher dose of tuber extract $\left(400 \mathrm{mg} \mathrm{kg}^{-1}\right.$ body weight per day). Similarly, progesterone concentration recovered by $19.40 \%(p>0.01)$ and $54.10 \%(p<0.05)$ in ethanol-treated

Table 1. Effect of ethanol extract of tuber of A. indica on oxidative stress parameters of ovarian tissue extract of rats. Significance level based on Kruskal Wallis non parametric ANOVA. Different letters indicate statistically significant differences between groups (mean \pm $\mathrm{SE}, n=5$, Mann-Whitney U multiple comparison test, $p<0.05$ )

\begin{tabular}{|c|c|c|c|c|c|}
\hline Parameter & Control & Ethanol treated & $\begin{array}{c}\text { Ethanol + } 200 \\
\text { EEAIT }\end{array}$ & $\begin{array}{c}\text { Ethanol }+400 \\
\text { EEAIT }\end{array}$ & $\begin{array}{c}\text { Kruskal Wallis } \\
\text { nonparametric } \\
\text { ANOVA }\end{array}$ \\
\hline $\mathrm{NO}\left(\mu \mathrm{M} \mathrm{mg}^{-1}\right.$ protein $)$ & $183.24 \pm 11.77 \mathrm{a}$ & $329.24 \pm 39.74 b$ & $242.95 \pm 17.91 \mathrm{c}$ & $225.90 \pm 24.05 \mathrm{~d}$ & $p<0.001$ \\
\hline $\mathrm{GSH}\left(\mathrm{mM} \mathrm{mg}^{-1}\right.$ protein) & $12.68 \pm 1.27 \mathrm{a}$ & $9.27 \pm 0.96 b$ & $10.69 \pm 1.20 c$ & $12.37 \pm 1.74 \mathrm{~d}$ & $p<0.05$ \\
\hline MDA (mM mg ${ }^{-1}$ protein) & $51.40 \pm 2.41 \mathrm{a}$ & $62.19 \pm 1.21 \mathrm{~b}$ & $55.88 \pm 2.58 c$ & $54.45 \pm 1.94 \mathrm{~d}$ & $p<0.01$ \\
\hline SOD activity ( $\mathrm{U} \mathrm{mg}^{-1}$ protein) & $55.81 \pm 5.77 \mathrm{a}$ & $39.53 \pm 4.65 b$ & $45.44 \pm 0.84 c$ & $52.23 \pm 3.82 \mathrm{de}$ & $p<0.001$ \\
\hline Catalase activity ( $\mathrm{U} \mathrm{mg}^{-1}$ protein $)$ & $6.90 \pm 1.45 \mathrm{a}$ & $2.23 \pm 0.38 b$ & $4.93 \pm 0.56 c$ & $6.72 \pm 1.18 \mathrm{de}$ & $p<0.01$ \\
\hline
\end{tabular}


Table 2. Effect of ethanol extract of tuber of A. indica on serum hormonal levels of rats. Significance level based on Kruskal Wallis non parametric ANOVA. Different letters indicate statistically significant differences between groups (mean \pm SE, $n=5$, Mann-Whitney $\mathrm{U}$ multiple comparison test, $p<0.05$ )

$\begin{array}{lccccc}\text { Parameter } & \text { Control } & \text { Ethanol treated } & \begin{array}{c}\text { Ethanol }+200 \\ \text { EEAIT }\end{array} & \begin{array}{c}\text { Ethanol + 400 } \\ \text { EEAIT }\end{array} & \begin{array}{c}\text { Kruskal Wallis } \\ \text { nonparametric } \\ \text { ANOVA }\end{array} \\ & 5.04 \pm 0.43 \mathrm{a} & 4.09 \pm 0.18 \mathrm{~b} & 4.91 \pm 0.44 \mathrm{c} & 4.72 \pm 0.64 \mathrm{~d} & p<0.05 \\ \text { FSH }\left(\mathrm{mIU} \mathrm{mL}^{-1}\right) & 8.17 \pm 0.57 \mathrm{a} & 5.91 \pm 0.71 \mathrm{~b} & 6.89 \pm 0.41 \mathrm{c} & 6.90 \pm 0.69 \mathrm{~d} & p<0.001 \\ \mathrm{LH}\left(\mathrm{mIU} \mathrm{mL}^{-1}\right) & 71.29 \pm 5.29 \mathrm{a} & 52.00 \pm 12.46 \mathrm{~b} & 60.92 \pm 16.09 \mathrm{c} & 71.01 \pm 10.57 \mathrm{~d} & p<0.05 \\ \text { Estrogen }\left(\mathrm{pg} \mathrm{mL}^{-1}\right) & 9.57 \pm 0.74 \mathrm{a} & 6.89 \pm 0.71 \mathrm{~b} & 7.41 \pm 1.34 \mathrm{c} & 8.34 \pm 1.10 \mathrm{~d} & p<0.05 \\ \text { Progesterone }\left(\mathrm{ng} \mathrm{mL}^{-1}\right) & 88.38 \pm 4.50 \mathrm{a} & 156.90 \pm 24.48 \mathrm{~b} & 121.88 \pm 8.95 \mathrm{c} & 100.79 \pm 12.45 \mathrm{de} & p<0.001 \\ \text { Corticosterone }\left(\mathrm{ng} \mathrm{mL}^{-1}\right) & 9.32 \pm 1.94 \mathrm{a} & 13.46 \pm 1.92 \mathrm{~b} & 10.20 \pm 1.34 \mathrm{c} & 10.36 \pm 1.15 \mathrm{~d} & p<0.05\end{array}$

rats supplemented with 200 and $400 \mathrm{mg} \mathrm{kg}^{-1}$ body weight per day of tuber extract, respectively (Table 2).

Plasma prolactin concentration was elevated by $44.42 \%$ $(p<0.05)$ (Table 2) in ethanol-treated rats compared to the control animals. Tuber extract administration resulted in significant recovery of ethanol-induced changes in plasma prolactin concentration, by $78.74 \%(p<0.01)$ and $74.87 \%$ $(p<0.01)$ at doses of 200 and $400 \mathrm{mg} \mathrm{kg}^{-1}$ body weight per day, respectively. In addition, increased concentration of plasma corticosterone $(77.52 \%, p<0.01)$ by ethanol intoxication recovered by $51.10 \%(p<0.01)$ and $81.88 \%$ $(p<0.01)$ (Table 2) after supplementation with the extract at doses of 200 and $400 \mathrm{mg} \mathrm{kg}^{-1}$ body weight per day, respectively.

The light microscopic evaluation of the ovaries in the ethanol-treated group showed severe necrotic changes in the ovary as compared to the normal architecture of the control group. In the control ovary, the primary and secondary follicles contained a distinct nucleus. All of the follicles showed the usual features with intact oocyte, antral

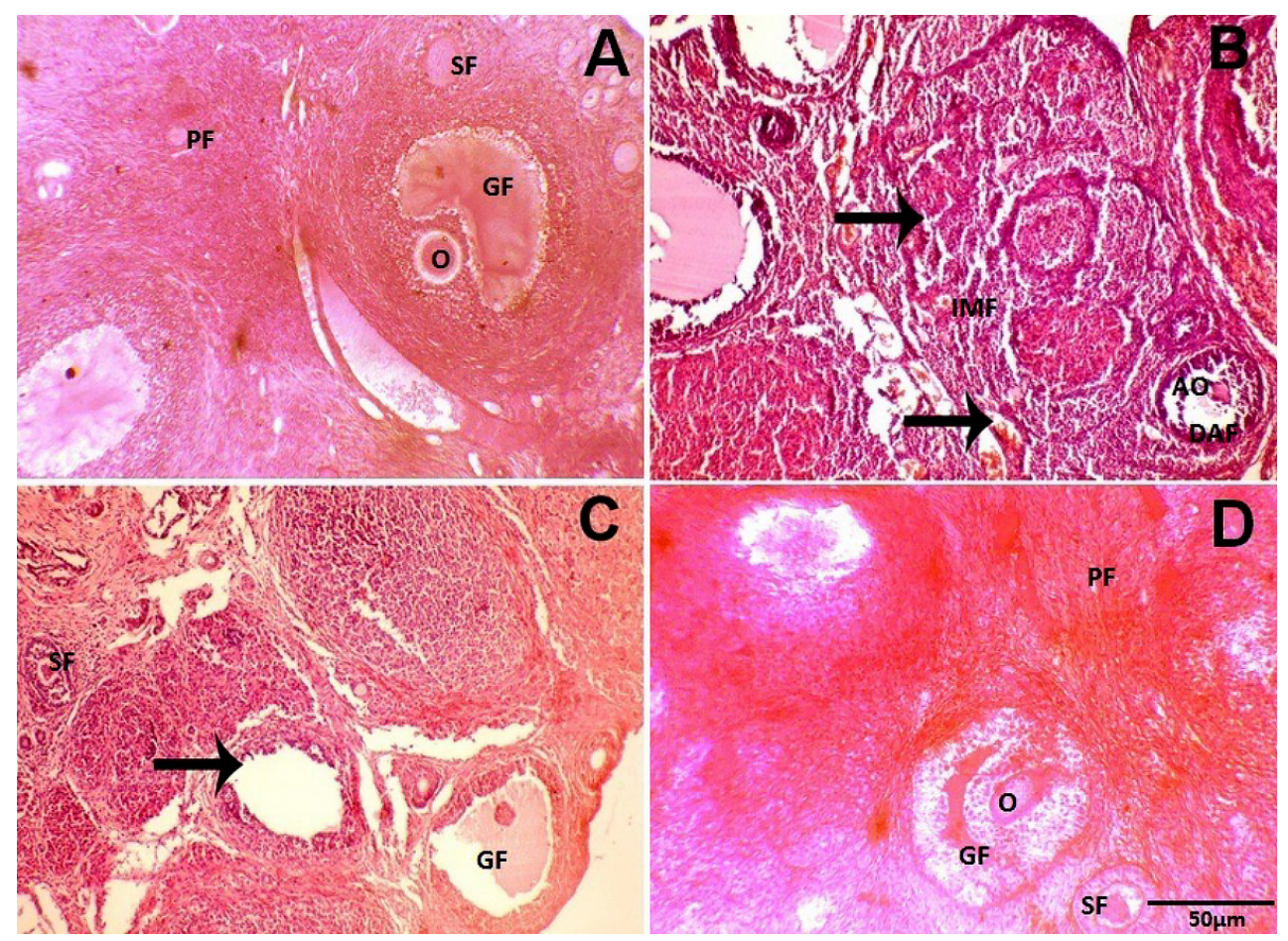

Fig. 1. Photographs of ovarian histopathology. Ovarian tissue from all groups of animals were collected and fixed in Bouin's-fixative. Paraffin blocks were prepared by the tissue and 4 to $5 \mu \mathrm{m}$-thin sections were cut with a rotary microtome. A, normal ovary section from untreated or healthy control rats, exhibiting normal architecture (PF, primary follicle; SF, secondary follicle; GF, Graafian follicle; O, oocyte). B, ethanol-treated ( $3 \mathrm{~g}$ per $\mathrm{kg}$ per day) rats show disintegration of granulosa cell layer as indicated by black arrow. The antral follicle was highly disintegrated without oocyte (DAF, AO) and presence of immature follicle (IMF). C and D, ovary section from ethanol intoxicated rats treated with ethanol extract of $A$. indica tuber at 200 and $400 \mathrm{mg}$ per $\mathrm{kg}$ per day, respectively, showed a lesser degree of granulosa cell layer disintegration and presence of primary (PF), secondary (SF) and Graafian follicle with oocyte (GF, O). Hematoxylin and eosin staining $(10 \times)$. 

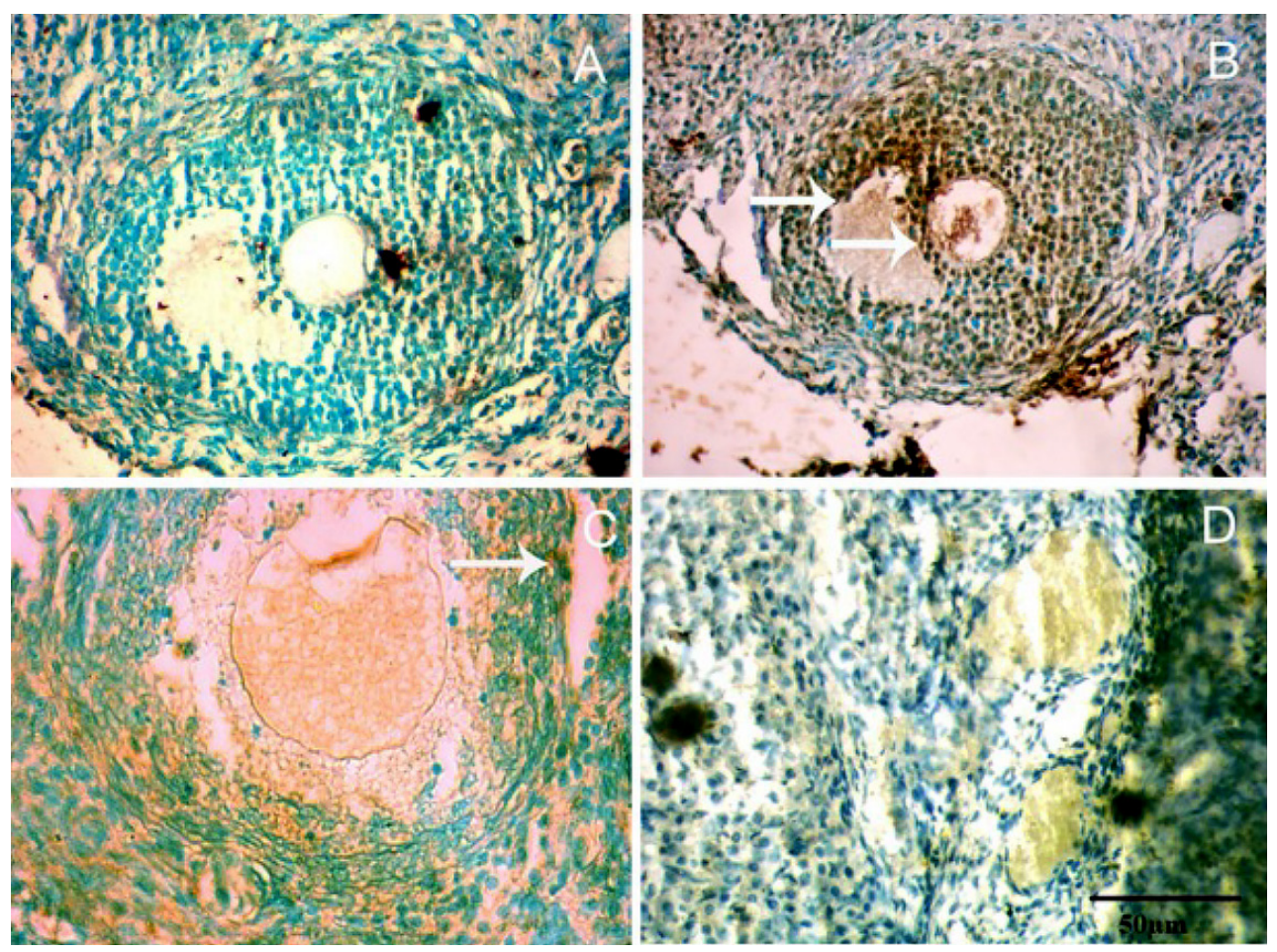

Fig. 2. TUNEL assays of ovary sections from rats treated with ethanol ( $3 \mathrm{~g}$ per kg per day) and supplemented with ethanol extract of $A$. indica tuber. Ovary section from control (A), treated with ethanol (B), treated with ethanol and ethanol extract of $A$. indica tuber at 200 $\mathrm{mg}$ per kg per day (C) and $400 \mathrm{mg}$ per kg per day (D). White arrow indicates apoptotic cells. Sections were taken at $40 \times$ magnifications.
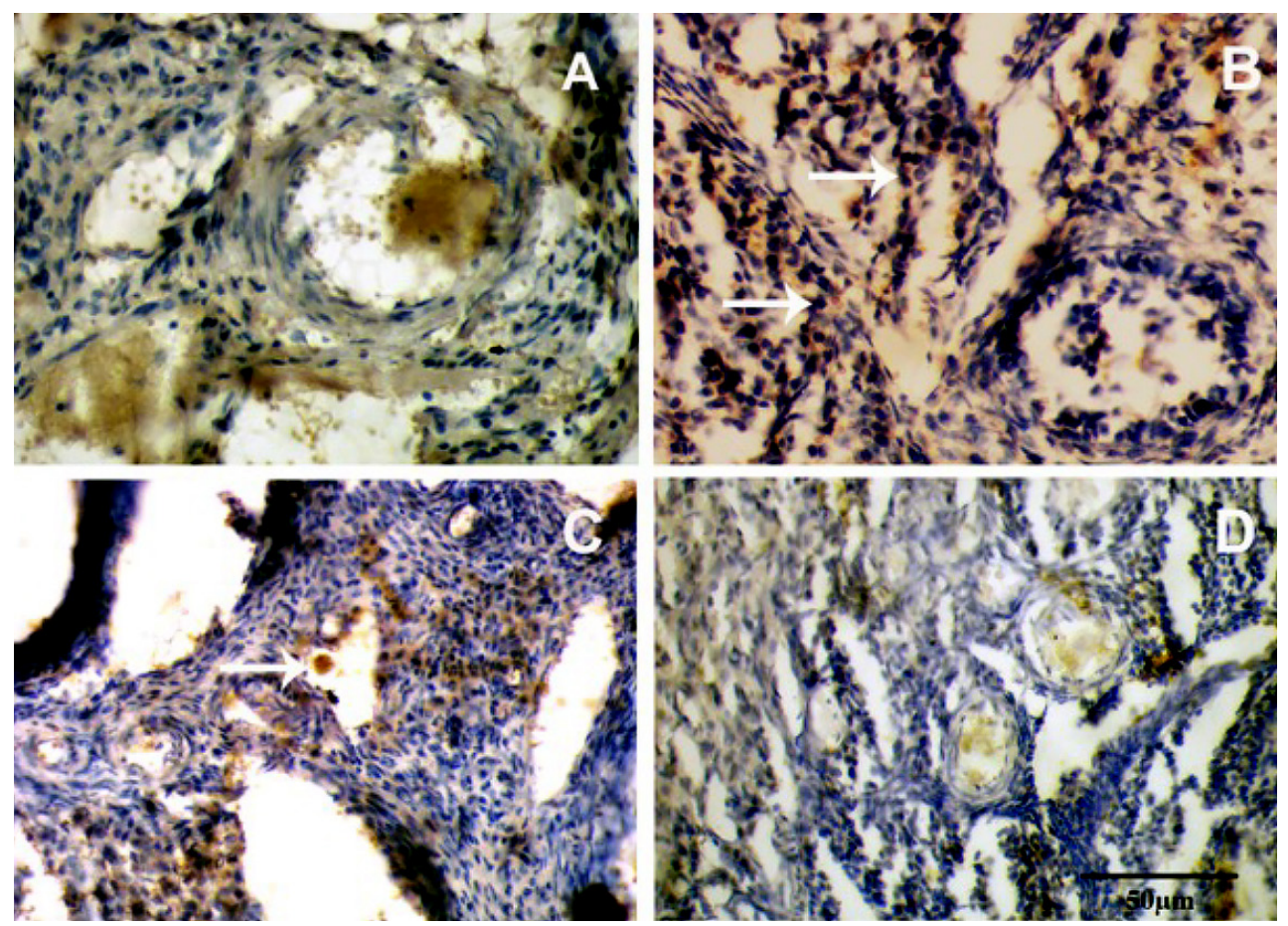

Fig. 3. NF-kB p65 expression in immunohistochemistry of ovary sections from rats in different experimental groups. A, ovary section from control showed normal architecture of the ovary section. B, a huge amount of apoptotic dead cells in ovary section of ethanoltreated rat indicated by white arrow. C, moderate apoptotic bodies resulting from ethanol extract of $A$. indica tuber administration at the concentration of $200 \mathrm{mg}$ per $\mathrm{kg}$ per day. D, almost normal architect of the ovary section in ethanol extract of $A$. indica tuber treatment at the concentration of $400 \mathrm{mg}$ per kg per day. All the sections were taken at $40 \times$ magnifications. 


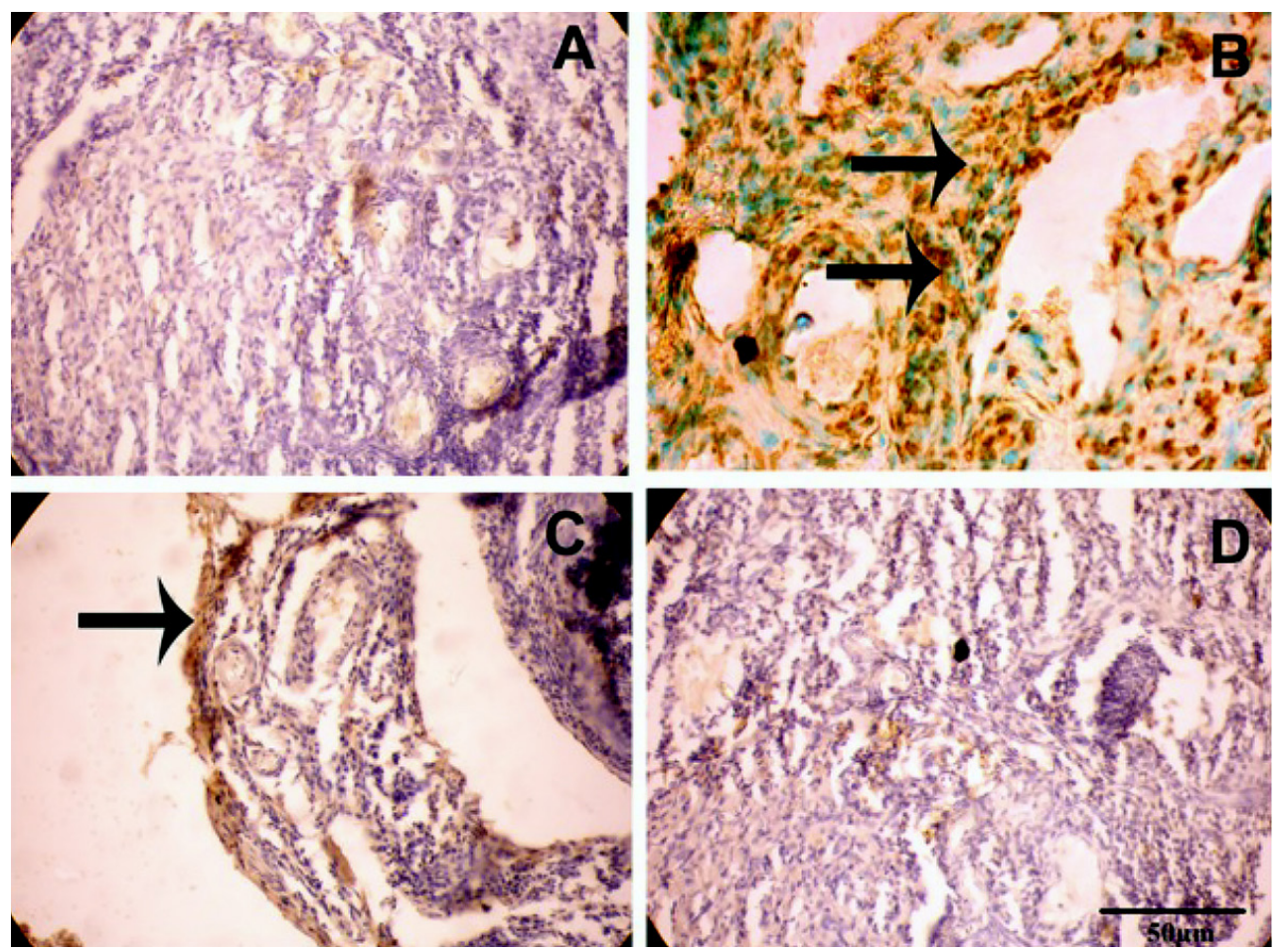

Fig. 4. Expression of caspase-3 in immunohistochemistry. A, ovary section from control showed normal architecture of the ovary section. B, a huge amount of apoptotic dead cells in ovary section of ethanol-treated rat indicated by white arrow. C, moderate apoptotic bodies resulting from ethanol extract of $A$. indica tuber administration at the concentration of $200 \mathrm{mg}$ per $\mathrm{kg}$ per day. $\mathrm{D}$, almost normal architect of the ovary section in ethanol extract of $A$. indica tuber treatment at the concentration of $400 \mathrm{mg}$ per $\mathrm{kg}$ per day. All the sections were taken at $40 \times$ magnifications.

follicle and zona pellucida (Fig. 1A), whereas the ovaries of the ethanol-treated animals lacked corpus lutea, had only small atretic follicles and consisted primarily of dense stroma. In addition, ethanol intoxicated ovaries showed a significant decrease in the number of graafian follicles, as well as degeneration in preovulatory follicles and atretic follicles (Fig. 1B). The antral follicle was highly disintegrated without oocyte due to ethanol treatment. These findings indicated early phases of ovarian injury in the ethanoltreated group. However, supplementation with tuber extract to the ethanol-treated rats at a concentration of 200 $\mathrm{mg} \mathrm{kg}^{-1}$ body weight per day (Fig. 1C) provided moderate protection of normal ovary morphology, as evidenced by the normal pattern of follicular cells. On the other hand, the extract at a concentration of $400 \mathrm{mg} \mathrm{kg}^{-1}$ body weight per day exhibited significant protection from ethanolinduced ovarian damage (Fig. 1D), as demonstrated by a noticeable increased number of primordial follicles as well as preovulatory follicles.

To determine whether ethanol-induced dysfunction of ovarian tissue was mediated by an apoptotic mechanism, terminal deoxynucleotidyl transferase dUTP nick end labeling (TUNEL) was performed. Results of the TUNEL assay showed no apoptotic nuclei in the control ovarian tissue (Fig 2A), although in ethanol-treated ovaries, large quantities of TUNEL positive cells were observed (black in colour indicated by arrow, Fig. 2B). Supplementation of tuber extract to the ethanol-treated rats significantly reduced the number of TUNEL positive cells (Fig. 2C, D).

Activated NF- $\kappa B$ was assessed by immunocytochemistry using activation specific monoclonal antibodies to NF$\kappa B$ p65 subunit, the epitope of which binds only after ІкB dissociation. Very few numbers of positively stained cells were observed in the control group (Fig. 3A), but many occurred in ovary sections of ethanol intoxicated rats (Fig. 3B). Tuber extract at a concentration of 200 (Fig. 3C) and $400 \mathrm{mg} \mathrm{kg}^{-1}$ body weight per day (Fig. 3D) were able to recover these ethanol induced changes to some extent as evidenced by reduction of numbers of positively stained cells from lower dose to the higher dose. Similar patterns of results were also obtained in the case of activated caspase- 3 (Fig. 4A-D).

\section{Discussion}

Protective efficacy of ethanol extract of tuber of Alocasia indica on alcohol-induced ovarian anomalies was observed in the present study. Various biomarkers of oxidative stress in ethanol intoxicated ovary were determined by measuring the nitric oxide (NO), lipid peroxidation (MDA) and reduced glutathione (GSH) content in ovarian tissue. Premature elevation of $\mathrm{NO}$ is reported to interfere with steroidogenesis at the critical time of ovarian maturation (Cymeryng et al. 2002). Thus, increased NO might be responsible for altered 
steroidogenesis in ethanol intoxicated ovary. Further, NO by means of its oxidant action may promote oxidative damage in the form of lipid peroxidation (Violoi et al. 1999). The elevated malondialdehyde (MDA) level, a marker of lipid peroxidation, in ovarian tissue of the ethanol-treated group, suggested increased lipid peroxidation. Administration of ethanol extract of tuber of $A$. indica resulted in lower concentration of both NO and MDA. Earlier we reported that ethanol extract of tuber of $A$. indica contained a large amount of phenol and flavonoid compounds (Pal et al. 2014a). GCMS analysis of ethanol extract of tuber of $A$. indica also showed many biologically active components, of which estra-1,3,5-(10)-trien-17-one,3-hydroxy-6methoxy, $O$-methyloxime was the major component and was found to be a phytosterol in nature (Pal et al. 2014a). Phenolic compounds can act as free radical scavengers by virtue of their hydrogen donating ability, forming aryloxyl radicals (Srinivasan et al. 2007). In addition, phenolics have also been found to interact with the oxidative cascade, preventing its outcome, quenching oxygen and making it less available for oxidative reaction (Yang et al. 2005). Thus, the phenolic and flavonoid compounds present in Alocasia indica tuber extract may account for its ability to decrease oxidative stress and impede tissue damage in the ovary.

Glutathione (GSH) plays significant roles in antioxidant defence, nutrient metabolism, and in regulation of cellular processes, including cell differentiation, proliferation and apoptosis. Glutathione provides considerable protection to cells by assisting in a cellular cascade of defence against oxidative stress. Depletion of glutathione leads to atresia of antral follicles in vivo and apoptosis of granulosa cells in cultured antral follicles (Devine et al. 2012). A previous study revealed that alcohol was capable of generating ROS by inhibiting glutathione synthesis, causing glutathione loss from the tissue and increasing MDA levels (Abdalla, 2011). In the present study, ethanol intoxication significantly reduced GSH concentration in ovarian tissue, suggesting that GSH acted as an antioxidant for the detoxification of toxic oxygen metabolites, intensifying the vulnerability of the ovarian tissue to oxidative damage. Supplementation with A. indica tuber ethanol extract (200 mg per kg bodyweight per day) resulted in recovery of ethanol-induced increased MDA production with a concomitant maintenance of the GSH level in the ovarian tissue, demonstrating the antioxidant action of GSH in maintenance of tissue function. Further, the recovery was enhanced when ethanol-treated rats were supplemented with a higher dose of tuber extract (400 mg per kg bodyweight per day).

SOD and catalase are known to be antioxidant enzymes and have a significant role in reducing oxidative stress (Agarwal et al. 2005). The increased levels of lipid peroxidation products found in ethanol-treated rats were also correlated with reduced activity of scavenging enzymes such as SOD and CAT. A decline in the activities of these enzymes can result in enormous availability of superoxides and peroxyradicals, which in turn produce hydroxyl radicals leading to propagation of lipid peroxidation. The present study affirmed that an elevated level of lipid peroxidation due to ethanol intoxication is linked with reduced SOD and CAT activity in ovarian tissue of rat. Supplementation with tuber extract at a concentration of $\left(200 \mathrm{mg} \mathrm{kg}^{-1}\right.$ body weight per day) reversed the ethanol-mediated changes in the activities of SOD and CAT to some extent, and this recovery was much more intensified when supplemented with a higher dose of tuber extract $\left(400 \mathrm{mg} \mathrm{kg}^{-1}\right.$ body weight per day). Polyphenols and flavonoids exhibit a wide range of biological and pharmacological activities both in vivo and in vitro (Rubio-Ruiz et al. 2019). They reduce cellular oxidative damage and possess anti-inflammatory properties. Thus, we speculate that the polyphenols and flavonoids present in ethanol extract of $A$. indica tuber scavenge free radicals generated due to ethanol intoxication in rat ovary and resulted in recovery of the activities of SOD and CAT as well as level of GSH.

Ethanol intoxication affects the hormonal levels of estrogen and progesterone, which leads to hyperprolactinemia (Olusola et al. 2014). Previously, it has been suggested that the optimal blood level of FSH is known to be a prerequisite for initiation and maintenance of normal ovarian folliculogenesis (Monfared and Salati 2013). A significant decrease in both FSH and estrogen levels indicated direct toxic effects of ethanol on ovary, which were reduced by ethanol extract of tuber of $A$. indica at both the lower (200 $\mathrm{mg} \mathrm{kg}^{-1}$ body weight per day) and higher (400 $\mathrm{mg} \mathrm{kg}^{-1}$ body weight per day) doses. Ethanol can suppress reproductive activity by inhibiting the release of $\mathrm{LH}$ as well as cause a reduction of gonadotropin-releasing hormone secretion from the hypothalamus (Ogilvie, Rivier 1997). This can be explained by a significant increase in the levels of LH and progesterone in ethanol-treated rat after administration of the lower dose of $A$. indica tuber ethanol extract supplementation and to a greater degree by the supplementation of the higher dose of tuber extract. These results suggest that polyphenols and flavonoids present in tuber extract limit the ethanol-mediated augmentation in NO generation, which in turn normalizes steroidogenesis. Restoration of steroidogenesis might be the cause for reducing the ethanol-mediated alteration in $\mathrm{LH}$ and FSH levels.

Among both premenopausal and postmenopausal women, an elevation in plasma prolactin levels has been reported following acute exposure to alcohol, which is associated with reproductive deficits in both males and females (Pierucci-Lagha et al. 2006). The specific mechanisms of the effect of alcohol exposure on plasma prolactin levels are not clear yet, but they may engage the opioid peptides and dopamine, which take part in the hypothalamic regulation of pituitary prolactin secretion (Freeman et al. 2000). Thus, increased level of prolactin may echo an activated opioid system, as acute alcohol intake 
has been demonstrated to secrete $\beta$-endorphin peptides in the rat hypothalamus (Oswald, Wand 2004) and raise the plasma $\beta$-endorphin level in human. High prolactin levels can also disrupt the normal ovulatory cycle in females. In the present study, a significant elevation of plasma prolactin level was found in ethanol-treated rats as compared to control animals, which is in complete agreement with earlier findings. Further, this elevated prolactin level was blunted by the supplementation of $A$. indica tuber ethanol extract.

Ethanol intoxication, like other types of drugs abuse, triggers the hypothalamus-pituitary-adrenal axis (Rivier 1996) leading to increased levels of acetylcholine and corticosterone in adulthood by stimulating corticotropinreleasing hormone and probably arginine vasopressin secretion from nerve terminals in the median eminence (Patterson-Buckendahl et al. 2005). Acute alcohol administration exhibits dose-related increases in acetylcholine and corticosterone, and females showed a greater response than males (Willey et al. 2012). In the current study, the plasma corticosterone level was found to be significantly higher in the ethanol-treated group as compared to control female rats. This suggested that chronic ethanol exposure possibly increases the synthesis and release of corticotrophin releasing factor, which in turn explains the increased levels of acetylcholine and corticosterone in ethanol intoxicated rats. However, in this study, only the level of corticosterone was measured. The elevated level of coticosterone was normalized by the administration of $A$. indica tuber ethanol extract in ethanol-treated rats.

Histopathological evaluation in this study clearly demonstrated that ethanol is a gonadal toxin in female. It produced marked disruption of normal ovarian architecture. Supplementation of ethanol extract of $A$. indica tuber enhanced the number of primary, secondary and antral ovarian follicles at concentration of $400 \mathrm{mg} \mathrm{kg}^{-1}$ body weight per day in ethanol-exposed rats.

The term 'follicular atresia' is used to characterize antral follicles going through degenerative alterations before becoming ruptured during ovulation. In mammals, the primary mechanism of follicular atresia is demonstrated to be apoptosis, while gonadotropins are involved in facilitating or hindering apoptotic mechanisms. Apoptosis is also the main mechanism behind the removal of corpus luteum during luteolysis (Niswender et al. 2000). Earlier studies on mice deficient in caspase-3 deficient demonstrated that caspase- 3 is needed for granulosa cell apoptosis and thus it is indispensible for the development of follicular atresia (Yang et al. 2004). The active form of caspase- 3 is classified as an "executioner" caspase and is responsible for the majority of cellular apoptotic events (Zimmermann et al. 2001). Hence, active caspase- 3 was selected as a representative protein for localization of apoptotic signalling within the ovary on exposure to ethanol. In the present study, there was a rapid increase in follicular apoptosis in ethanoltreated ovaries, as determined by TUNEL staining and active caspase- 3 immunolabeling. This finding suggested a relatively prompt induction of increased ovarian apoptotic cell death and implicated apoptosis as an initial process in ethanol-induced ovarian damage. Our observations proved that ethanol extract of $A$. indica tuber at lower and higher (200 and $400 \mathrm{mg} \mathrm{kg}^{-1}$ body weight per day) doses could mitigate the ethanol induced apoptosis and ovarian damage in female rats.

Nuclear factor $\kappa \mathrm{B}(\mathrm{NF}-\mathrm{\kappa B})$ is a nuclear transcription factor that regulates expression of a large number of genes that are critical for the regulation of apoptosis, viral replication, tumourigenesis, inflammation and various autoimmune diseases (Cervantes-Flores et al. 2011). In our study, the results showed that expression of NF- $\mathrm{kB}$ was increased in the ethanol-treated ovaries, which was counteracted by the supplementation of ethanol extract of A. indica tuber at lower and higher $(200$ and $400 \mathrm{mg}$ $\mathrm{kg}^{-1}$ body weight per day) doses. This may reflect the antiinflammatory activity of this extract by reducing expression of NF-kB, as flavonoids have been found to possess antiinflammatory activity in both proliferative and exudative phases of inflammation (Rathee et al. 2009). Hence, ethanol extract of $A$. indica tuber can act as a protective agent against inflammatory insults due to ethanol use, which may favour pregnancy.

\section{Conclusions}

The results of the present study suggest that alcohol produces ovarian dysfunction by disrupting all three control points of the hypothalamic-pituitary-gonadal axis. Normal ovarian architecture and hormonal balance were altered by the toxic effect of ethanol. The ethanol-induced reduction of gonadotropin-releasing hormone secretion by the hypothalamus appears to be greater than the reduction in gonadotropin secretion by the pituitary. Moreover, it was also observed that ethanol produced apoptotic cell death in ovarian tissue, which may be a causative effect of gonadal dysfunction. According to our previous study, ethanol extracts of Alocasia indica tuber contained a significant amount of biologically active components like phenolic and flavonoid compound. Thus, the ethanol extracts of $A$. indica tuber help to prevent ethanol-induced disruption of ovarian function and apoptotic cell death, which is possibly due to presence of antioxidant and phytosterol components in it. However, to elucidate the exact mechanism of this modulator effect, further studies are essential.

\section{Acknowledgements}

The research was financially supported by the grants from CSIR, Govt. of India. 


\section{References}

Abdalla M.Y. 2011. Glutathione as potential target for cancer therapy; more or less is good? Jordan. J. Biol. Sci. 4: 119-124.

Agarwal A., Gupta S., Sharma R.K. 2005. Role of oxidative stress in female reproduction. Reprod. Biol. Endocrinol. 3: 28.

Albano E. 2006. Alcohol, oxidative stress and free radical damage. Proc. Nutr. Soc. 65: 278-290.

Cederbaum A.I. 2012. Alcohol metabolism. Clin. Liver Dis. 16: 667-685.

Cervantes-Flores M., Martínez-Romero A., Ramírez-Valles E.G., Mendiola L.S., Moreno-Lafont M.C., López-Moreno R., Estrada-Garcia I., Mojica-Marín V. 2011. NFB is differentially activated in macrophages from J774A. 1 cell line infected with vaccine or virulent strains of Brucella abortus. Afr. J. Microbiol. Res. 5: 941-949.

Cymeryng C.B., Lotito S.P., Colonna C., Finkielstein C., Pomeraniec Y., Grión N., Gadda L., Maloberti P., Podestá E.J. 2002. Expression of nitric oxide synthases in rat adrenal zona fasciculata cells. Endocrinology 143: 1235-1242.

Devine P.J., Perreault S.D., Luderer U. 2012. Roles of reactive oxygen species and antioxidants in ovarian toxicity. Biol. Reprod. 86: 1-10.

Ely M., Hardy R., Longford N.T., Wordsworth M.E. 1999. Gender differences in the relationship between alcohol consumption and drink problems are largely accounted for by body water. Alcohol Alcoholism 34: 894-902.

Emanuele M.A., Wezeman F., Emanuele N.V. 2002. Alcohol's effects on female reproductive function. Alcohol Res. Health 26: $274-281$.

Erol A., Karpyak V.M. 2015. Sex and gender-related differences in alcohol use and its consequences: Contemporary knowledge and future research considerations. Drug Alcohol Depend. 156: $1-13$.

Freeman M.E., Kanyicska B., Lerant A., Nagy G. 2000. Prolactin: structure, function, and regulation of secretion. Physiol. Rev. 80: 1523-1631.

Giakoustidis A., Giakoustidis D., Koliakou K., Kaldrymidou E., Iliadis S., Antoniadis N., Kontos N., Papanikolaou V., Papageorgiou G., Atmatzidis K., Takoudas D. 2008. Inhibition of intestinal ischemia/repurfusion induced apoptosis and necrosis via down-regulation of the NF-kB, c-Jun and caspace3 expression by epigallocatechin-3-gallate administration. Free Radic. Res. 42: 180-188.

Kirtikar K.R., Basu B.D. 1975. Indian Medicinal Plants. $2^{\text {nd }}$ Ed. Oriental Enterprises, Dehradun.

Kono H., Arteel G.E., Rusyn I., Sies H., Thurman R.G. 2001. Ebselen prevents early alcohol-induced liver injury in rats. Free Radic. Biol. Med. 30: 403-411.

Lowry O.H., Rosebrough N.J., Farr A.L., Randall R.J. 1951. Protein measurement with the Folin phenol reagent. J. Biol. Chem. 193: 265-275.

Mlejnek P. 2001. Caspase inhibition and N6-benzyladenosineinduced apoptosis in HL-60 cells. J. Cell. Biochem. 83: 678689.

Monfared A.L., Salati A.P. 2013. Effects of Carthamus tinctorius L. on the ovarian histomorphology and the female reproductive hormones in mice. Avicenna J. Phytomed. 3: 171-177.

Mulla W.A., Salunkhe V.R., Bhise S.B. 2009. Hepatoprotective activity of hydroalcoholic extract of leaves of Alocasia indica (Linn.). Indian J. Exp Biol. 47: 816-821.

Niswender G.D., Juengel J.L., Silva P.J., Rollyson M.K., McIntush
E.W. 2000. Mechanisms controlling the function and life span of the corpus luteum. Physiol Rev. 80: 1-29.

Ogilvie K.M., Rivier C. 1997. Effect of alcohol on the proestrous surge of luteinizing hormone ( $\mathrm{LH})$ and the activation of LH-releasing hormone (LHRH) neurons in the female rat. $J$. Neurosci. 7: 2595-2604.

Olusola A.E., Helen O.T., Abiodun A.D., Udo N.V. 2014. Sexual functions, sexual organs and sex hormone level in chronic alcohol intake. Brit. J. Med. Med. Res. 4: 1279-1292.

Oswald L.M., Wand G.S. 2004. Opioids and alcoholism. Physiol Behav. 81: 339-358.

Pal S., Bhattacharjee A., Mukherjee S., Bhattacharya K., Khowala S. 2014a. Antioxidant and hepatoprotective activity of ethanolic extract of Alocasia indica tuber. Amer. J. Phytomed. Clin. Ther. 2: 191-208.

Pal S., Bhattacharjee A., Mukherjee S., Bhattacharya K., Mukherjee S., Khowala S. 2014b. Effect of Alocasia indica tuber extract on reducing hepatotoxicity and liver apoptosis in alcohol intoxicated rats. BioMed Res. Int. 2014: 349074.

Patterson-Buckendahl P., Kubovcakova L., Krizanova O., Pohorecky L.A., Kvetnansky R. 2005. Ethanol consumption increases rat stress hormones and adrenomedullary gene expression. Alcohol 37: 157-166.

Pierucci-Lagha A., Covault J., Feinn R., Khisti R.T., Morrow A.L., Marx C.E., Shampine L.J., Kranzler H.R. 2006. Subjective effects and changes in steroid hormone concentrations in humans following acute consumption of alcohol. Psychopharmacology 186: 451-461.

Prajapati ND. 2003. A Handbook of Medicinal Plants. Agrobios India, Jodhpur.

Prasad S.k., Bose A., Bhattacharjee A., Banerjee O., Singha S., Mukherjee S., Pal S. 2019. Radioprotective effect of ethanolic extract of Alocasia indica on c-irradiation-induced reproductive alterations in ovary and uterus. Int. J. Radiat. Biol. 95: 1529-1542.

Rahmatullah M., Ferdausi D., Mollik A.H., Jahan R., Chowdhury M.H., Haque W.M. 2009. A survey of medicinal plants used by Kavirajes of Chalna area, Khulna district, Bangladesh. Afr. J. Tradit. Complement. Altern. Med. 7: 91-97.

Rathee P., Chaudhary H., Rathee S., Rathee D., Kumar V., Kohli K. 2009. Mechanism of action of flavonoids as anti-inflammatory agents: a review. Inflamm. Allergy Drug Targets 8: 229-235.

Redza-Dutordoir M., Averill-Bates D.A. 2016. Activation of apoptosis signalling pathways by reactive oxygen species. Bioch. Biophys. Acta 1863: 2977-2992.

Rivier C. 1996. Alcohol stimulates ACTH secretion in the rat: mechanisms of action and interactions with other stimuli. Alcohol Clin. Exp. Res. 20: 240-254.

Rubio-Ruiz, M. E., Guarner-Lans, V., Cano-Martínez, A., DíazDíaz, E., Manzano-Pech, L., Gamas-Magaña, A., CastrejónTellez, V., Tapia-Cortina, C., Pérez-Torres, I. 2019. Resveratrol and quercetin administration improves antioxidant defenses and reduces fatty liver in metabolic syndrome rats. Molecules 24: 1297.

Srilatha B.R., Ananda S. 2014. Antidiabetic effects of Mukia maderaspatana and its phenolics: An in vitro study on gluconeogenesis and glucose uptake in rat tissues. Pharm. Biol. 52: 597-602.

Srinivasan M., Sudheer A.R., Menon V.P. 2007. Ferulic acid: therapeutic potential through its antioxidant property. J. Clin. Biochem. Nutr. 40: 92-100.

Tegeder I., Pfeilschifter J., Geisslinger G. 2001. Cyclooxygenase- 
independent actions of cyclooxygenase inhibitors. FASEB J. 15: 2057-2072.

Violi F., Marino R., Milite M.T., Loffredo L. 1999. Nitric oxide and its role in lipid peroxidation. Diabetes Metab. Res. Rev. 15: 283288.

Waldron M., Heath A.C., Bucholz K.K., Madden P.A., Martin NG. 2008. Alcohol dependence and reproductive onset: Findings in two Australian twin cohorts. Alcohol Clin. Exp. Res. 32: $1865-1874$.

Willey A.R., Anderson R.I., Morales M., Ramirez R.L, Spear L.P. 2012. Effects of ethanol administration on corticosterone levels in adolescent and adult rats. Alcohol 46: 29-36.

Yang F., Lim G.P., Begum A.N., Ubeda O.J., Simmons M.R., Ambegaokar S.S., Chen P.P., Kayed R., Glabe C.G., Frautschy S.A., Cole G.M. 2005. Curcumin inhibits formation of amyloid $\beta$ oligomers and fibrils, binds plaques, and reduces amyloid in vivo. J. Biol. Chem. 280: 5892-5901.

Yang X., Yao H., Wang Y. 2004. Advances in the research of oocyte apoptosis in mammals. Chin. J. Zool. 39: 101-106.

Zimmermann K.C., Bonzon C., Green D.R. 2001. The machinery of programmed cell death. Pharmacol Ther. 92: 57-70. 